\title{
Division-inhibition capacity of penicillin in Escherichia coli is growth-rate dependent
}

\author{
Hilla Hadas, Monica Einav, Itzhak Fishov and Arieh Zaritsky
}

Author for correspondence: Hilla Hadas. Tel: +972 $7461712 /+9727278$ 951. Fax: +972 7278 951/+972 7

276 201.e-mail: ariehz@bgumail.bgu.ac.il

Department of Life Sciences, Ben-Gurion University of the Negev, PO Box 653, Be'erSheva, Israel 84105

\author{
Growing bacteria are sensitive to various $\beta$-lactam derivatives due to their \\ interference with peptidoglycan biosynthesis. At low concentrations, penicillin \\ G (benzylpenicillin) blocks cell division without affecting mass growth rate. \\ The MIC for division of Escherichia coll B/r (H266) was found to depend on the \\ growth rate, which was modified by the nutritional conditions. Our \\ hypothesis, that division sensitivity is proportional to the rate of \\ peptidoglycan synthesis for septum formation, as well as to cell circumference, \\ was thus confirmed.
}

Keywords: Escherichia coli, $\beta$-lactam, penicillin G, FtsZ ring, penicillin-binding proteins

\section{INTRODUCTION}

Various $\beta$-lactam derivatives have high specific affinities to their target molecules, penicillin-binding proteins (PBPs), which are involved in bacterial peptidoglycan biosynthesis (Spratt, 1983; Waxman \& Strominger, 1983). Growing cells are therefore sensitive to these drugs. At high concentrations, most of them cause cell lysis in Escherichia coli by inactivating all the PBPs (Spratt, 1975, 1983; Waxman \& Strominger, 1983). The time and rate of lysis are proportional, respectively, to the generation time $(\tau)$ and its inverse, growth rate $(\mu)$, determined by the medium composition (Boman \& Eriksson, 1963; Tuomanen et al., 1986).

At low concentrations, different $\beta$-lactams exert various physiological effects according to their relative affinities for the distinct PBPs (Botta \& Park, 1981; Spratt, 1975; Wientjes \& Nanninga, 1991). Blocking PBP-1, which is responsible for cell elongation (probably by priming peptidoglycan chains) results in cell lysis; blocking PBP-2, which governs cell shape, results in ovoid cells; blocking PBP-3, which is solely required for septal murein synthesis, results in filamentation. Furazlocillin, ampicillin, cephalexin and penicillin G (benzylpenicillin) at low concentrations bind preferentially to PBP-3, and they inhibit cell division without affecting net peptidoglycan synthesis, mass growth and DNA replication (Donachie, 1993; Spratt, 1975). The question thus arises whether the MIC for division depends on the nutritional conditions as does the MIC for lysis.

\section{METHODS}

E. coli $\mathrm{B} / \mathrm{r}$ (H266) was cultivated in Luria-Bertani broth supplemented with glucose $(0.4 \%$; LBG), and in M9 minimal medium (Miller, 1972) supplemented with $1 \%(\mathrm{w} / \mathrm{v}$ ) casein hydrolysate and tryptophan $\left(20 \mu \mathrm{g} \mathrm{ml}^{-1}\right.$; Casa) or supplemented with $0.4 \%$ of either glucose, glycerol or acetate as the sole carbon source. Doubling times of 22-25, 29-31, 45-50, 68-70 and $120-140 \mathrm{~min}$, respectively, were observed, as previously documented (Rosenberger et al., 1978; Zaritsky et al., 1979). Each experiment was performed with a steady-state growing culture (Fishov et al., 1995), after diluting $\left(10^{-3}\right)$ an overnight culture into the same medium (pre-warmed), vigorously aerated at $37^{\circ} \mathrm{C}$ in a gyratory water-bath shaker ( 250 r.p.m.). Growth was monitored by cell number using Coulter Counter model $\mathrm{ZM}$ and by measuring $\mathrm{OD}_{450}$ using an LKB Ultrospec II spectrophotometer. Steady-state growth was maintained by appropriate dilutions in fresh, pre-warmed medium (below $\mathrm{OD}_{450} \sim 0.4$ ) and demonstrated by the Kolmogorov-Smirnov test for size distributions in successive generations (Woldringh et al., 1977). Treatment of each steady-state culture was initiated by dilution (to $\mathrm{OD}_{450} \sim 0.06$ ) into medium containing penicillin $\mathrm{G}$ (Sigma) at the indicated concentrations. The rate of mass growth was not affected by these penicillin concentrations.

\section{RESULTS AND DISCUSSION}

The division-inhibition capacity of penicillin clearly depends on growth rate (Fig. 1). At 20 units ml$^{-1}$, penicillin blocks division in acetate culture completely, and blocks approximately $90,80,35$ and $20 \%$ of division in glycerol-, glucose-, Casa- and LBG-grown cells, respectively. The corresponding penicillin concentrations that halve the rate of division $\left(\mathrm{Pn}_{50}\right)$ are $5 \cdot 2,10 \cdot 0,13 \cdot 2$, $25 \cdot 4$ and 47.5 units $\mathrm{ml}^{-1}$ (Fig. 2). 

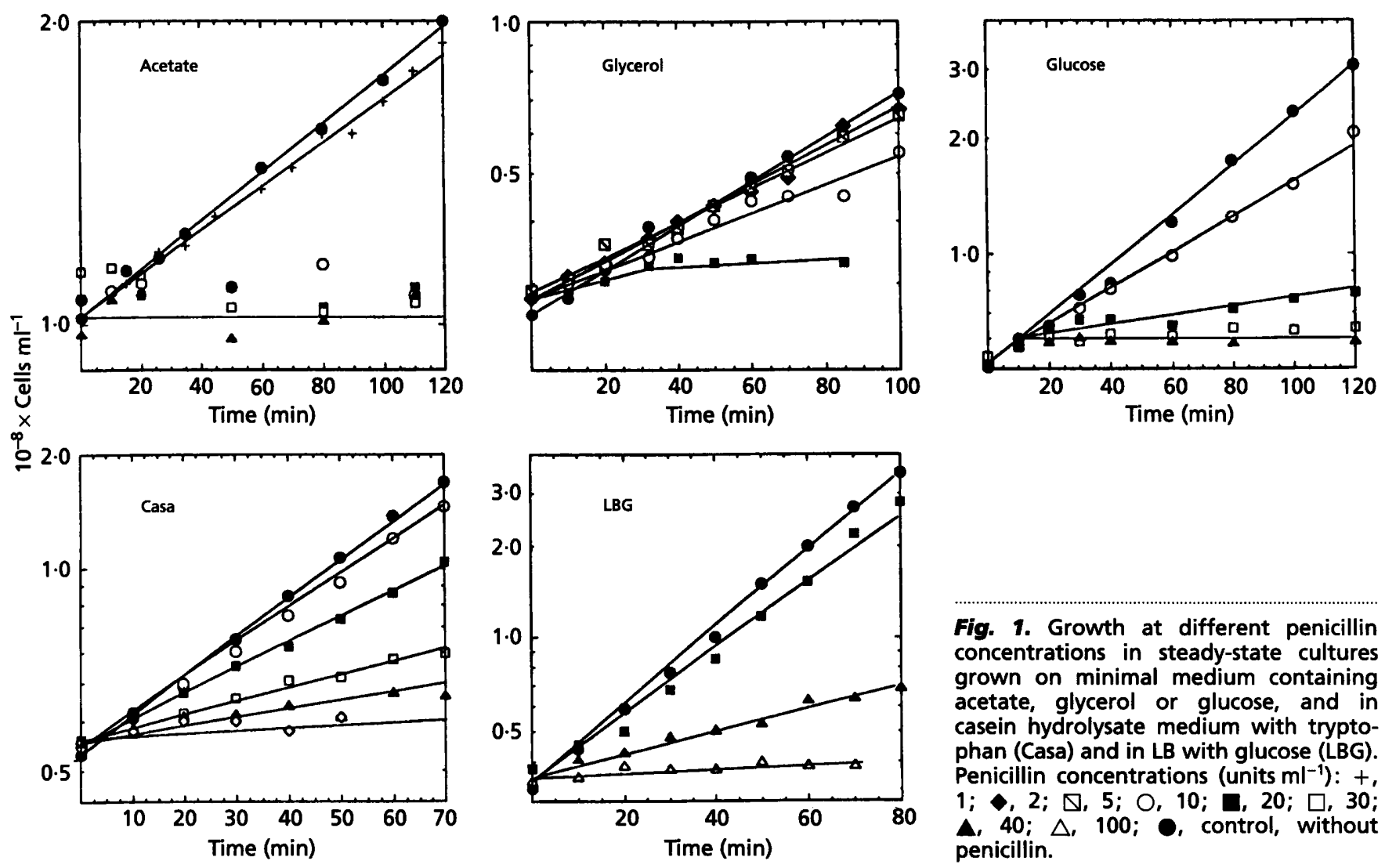

Fig. 1. Growth at different penicillin concentrations in steady-state cultures grown on minimal medium containing acetate, glycerol or glucose, and in casein hydrolysate medium with tryptophan (Casa) and in LB with glucose (LBG). Penicillin concentrations (units $\mathrm{ml}^{-1}$ ): + , $1 ; \bullet, 2 ; \nabla, 5 ; 0,10 ; \square, 20 ; \square, 30$; $\Delta, 40 ; \triangle, 100$; 0 , control, without penicillin.

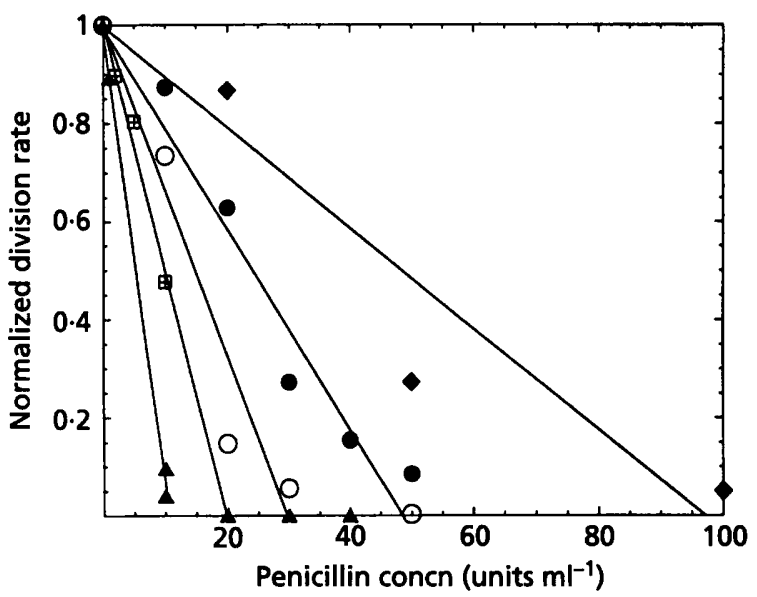

Fig. 2. Inhibition of cell division by penicillin in different growth media. Division rates (slopes from Fig. 1), normalized to 1.0 in each control experiment, were plotted against penicillin concentration. $\diamond$, LBG $(y=0.975-0.010 x$, correlation coefficient $R=-0.96) ; 0$, Casa $(y=1.009-0.020 x, R=-0.98) ; 0$, glucose $(y=0.998-0.034 x, R=-0.97)$; $\boxplus$, glycerol $(y=1.013-0.051 x$, $R=-0.99) ; \triangle$, acetate $(y=1.080-0.096 x, R=-0.97)$.

Bacterial cell division occurs a constant time after termination of DNA replication over a wide range of growth rates (Helmstetter et al., 1968). Thereafter, cell division is no longer dependent on synthesis of macromolecules other then peptidoglycan for septum formation
(Donachie, 1993). Septation is apparently initiated by selfassembly of the Fts Z ring in the membrane ( $\mathrm{Bi} \&$ Lutkenhaus, 1991) surrounding the DNA-free gap formed upon disassociation between the two sister nucleoids (Mulder \& Woldringh, 1989; Woldringh et al., 1990). The activity of PBP-3 as an enzyme involved in septation is expressed after FtsZ ring formation (Donachie, 1993), and would be inhibited by penicillin. The sensitivity of division at low penicillin concentrations will thus depend upon the length of that ring (cell circumference), as well as on the rate of peptidoglycan synthesis for septum formation, which is presumed to be proportional to $\mu$. Cell circumference $(2 \pi r)$ is determined by cell radius $(r)$, which is known to change regularly with growth rate (Rosenberger et al., 1978; Woldringh et al., 1977). At a faster $\mu$ (shorter $\tau$ ), the cell must therefore produce a bigger cross-wall during a shorter time. If the density of PBP-3 involved in septation does not vary with growth rate, the penicillin concentration needed to reduce the rate of cell division to a certain extent will therefore be proportional to $r \times \mu$ (i.e. $k \times$ penicillin concn $=r / \tau$ ). This prediction is confirmed by the data (Table 1), as shown by the relatively constant proportionality coefficient ( $k=0.00274 \pm 0.00048)$, and is consistent with the invariant duration ( $T$ period) of the process of cell constriction at different growth rates (Woldringh et al., 1977).

Our data support the conclusion that PBP-3 plays a major role in the regulation of cell division, as indicated by the small number of molecules a cell contains (Spratt, 1977). 
Table 1. Effects of growth medium on penicillin division-inhibition parameters

\begin{tabular}{|c|c|c|c|c|}
\hline $\begin{array}{l}\text { Growth } \\
\text { medium }\end{array}$ & $\begin{array}{l}\text { Generation } \\
\text { time } \tau \text { (min) }\end{array}$ & $\begin{array}{c}\mathbf{P n}_{50}{ }^{*} \\
\text { (units } \mathrm{ml}^{-1} \text { ) }\end{array}$ & $\begin{array}{c}\text { Cell } \\
\text { circumference } \dagger \\
(\mu \mathrm{m})\end{array}$ & $\begin{array}{c}k \ddagger\left(\mu \mathrm{m} \mathrm{min} \min ^{-1}\right) / \\
\text { (units } \mathrm{ml}^{-1} \text { ) }\end{array}$ \\
\hline LBG & 23 & $47 \cdot 5$ & $2 \cdot 90$ & 0.00265 \\
\hline Casa & 30 & $25 \cdot 4$ & $2 \cdot 51$ & 0.00319 \\
\hline Glucose & 48 & $13 \cdot 2$ & 1.95 & 0.00308 \\
\hline Glycerol & 70 & $10 \cdot 0$ & $1 \cdot 79$ & 0.00256 \\
\hline Acetate & 130 & $5 \cdot 2$ & $1 \cdot 51$ & 0.00223 \\
\hline
\end{tabular}

* Penicillin concentration that inhibits the rate of cell division by $50 \%$; calculated from Fig. 2 .

† Calculated from cell radius ( $r$ ); taken from Woldringh et al. (1990).

$\ddagger$ Penicillin activity coefficient $(k)$; calculated by dividing the cell circumference by the doubling time $\tau$ and then dividing by $\mathrm{Pn}_{50}\left(2 \pi r / \tau / \mathrm{Pn}_{50}\right)$.

\section{ACKNOWLEDGEMENTS}

This study was supported in part by grant no. 91-00190 from the US-Israel Binational Science Foundation (BSF), Jerusalem (to A.Z.) and the Ben-Gurion Fellowship administered by the Ministry of Sciences and the Arts (to H.H.).

\section{REFERENCES}

Bi, E. \& Lutkenhaus, J. (1991). FtsZ ring structure associated with division in Escherichia coli. Nature 354, 161-164.

Boman, H. G. \& Eriksson, K. G. (1963). Penicillin induced lysis in Escherichia coli. J Gen Microbiol 31, 339-352.

Botta, G. A. \& Park, J. T. (1981). Evidence for involvement of penicillin-binding protein 3 in murein synthesis during septation but not during cell elongation. $J$ Bacteriol 145, 333-340.

Donachie, W. D. (1993). The cell cycle of Escherichia coli. Annu Rev Microbiol 47, 199-230.

Fishov, I., Zaritsky, A. \& Grover, N. B. (1995). On microbial states of growth. Mol Microbiol 15, (in press).

Helmstetter, C. E., Cooper, S., Pierucci, O. \& Revelas, L. (1968). The bacterial life sequence. Cold Spring Harbor Symp Quant Biol 33, 809-822.

Miller, J. H. (1972). Experiments in Molecular Genetics. Cold Spring Harbor, NY: Cold Spring Harbor Laboratory.

Mulder, E. \& Woldringh, C. L. (1989). Actively replicating nucleoids influence positioning of division sites in Escherichia coli filaments forming cells lacking DNA. J Bacteriol 171, 4303-4314.

Rosenberger, R. F., Grover, N. B., Zaritsky, A. \& Woldringh, C. L. (1978). Surface growth in rod-shaped bacteria. $J$ Theor Biol 73, 711-721.

Spratt, B. G. (1975). Distinct penicillin binding proteins involved in the division, elongation, and shape of Escherichia coli K-12. Proc Natl Acad Sci US A 72, 2999-3003.

Spratt, B. G. (1977). Properties of the penicillin-binding proteins of Escherichia coli K-12. Eur J Biochem 72, 341-352.

Spratt, B. G. (1983). Penicillin-binding proteins and the future of $\beta$ lactam antibiotics. J Gen Microbiol 129, 1247-1260.

Tuomanen, E., Cozens, R., Tosch, W., Zak, O. \& Tomasz, A. (1986). The rate of killing of Escherichia coli by $\beta$-lactam antibiotics is strictly proportional to the rate of bacterial growth. J Gen Microbiol 132, $1297-1304$.

Waxman, D. J. \& Strominger, J. L. (1983). Penicillin-binding proteins and the mechanism of action of $\beta$-lactam antibiotics. Annu Rev Biochem 52, 825-869.

Wientjes, F. B. \& Nanninga, N. (1991). On the role of the high molecular weight penicillin-binding proteins in the cell cycle of Escherichia coli. Res Microbiol 142, 333-344.

Woldringh, C. L., de Jong, M. A., van den Berg, W. \& Koppes, L. (1977). Morphological analysis of the division cycle of two substrains during slow growth. J Bacteriol 131, 270-279.

Woldringh, C. L., Mulder, E., Valkenburg, J. A. C., Wientjes, F. B., Zaritsky, A. \& Nanninga, N. (1990). Role of the nucleoid in the toporegulation of division. Res Microbiol 141, 39-49.

Woldringh, C. L., Huls, P. G. \& Vischer, N. O. (1993). Volume growth of daughter and parent cells during the cell cycle of Saccharomyces cerevisiae a $\alpha$ as determined by image cytometry. $J$ Bacteriol 175, 3174-3181.

Zaritsky, A., Woldringh, C. L. \& Mirelman, D. (1979). Constant peptidoglycan density in the sacculus of Escherichia coli $\mathrm{B} / \mathrm{r}$ growing at different rates. FEBS Lett 98, 29-32.

Received 14 October 1994; revised 28 December 1994; accepted 3 January 1995. 